\title{
A Field Observation of the Critically Endangered Indian Gharial, Gavialis gangeticus (Gemlin 1789), in the Lower Ganga Canal, Narora, Uttar Pradesh, India
}

\author{
Debanjan Sarkar ${ }^{1}$, Chinnasamy Ramesh ${ }^{1}$, Syed Ainul Hussain ${ }^{1}$, Raja Mondal ${ }^{2}$, and Gautam Talukdar ${ }^{1}$ \\ ${ }^{1}$ Wildlife Institute of India, Chandrabani, Dehradun-248001, Uttarakhand, India (ramesh.czoo@gmail.com) \\ ${ }^{2}$ Narora Atomic Power Station, Narora, Uttar Pradesh, India
}

$\mathrm{O}$ f the 24 extant species of crocodilians (Martin 2008), three occur in India: the Gharial, Gavialis gangeticus (Gemlin 1789); the Mugger, Crocodylus palustris (Lesson 1831); and the Estuarine Crocodile, Crocodylus porosus Schneider 1801. The Gharial (Gavialidae) is one of an ancient group of crocodilians most of which are extinct, hence this species is considered a living fossil (Vasudevan and Sondhi 2010). The Gharial is a river-dwelling species distinguished by its enormously long, thin jaws, which are considered an adaptation for its dependence on a diet of fish (Stevenson and Whitaker 2010). The name is derived from the bulbous cartilaginous growth on the end of the snout of adult males that resembles an earthenware pot called a ghara (Smith 1931).
This species is listed as Critically Endangered on the IUCN Red List (Choudhury et al. 2007) and is considered the most endangered large animal on the Indian Subcontinent and one of the most endangered of all crocodilians (GCA 2008). It is a keystone species of running freshwater ecosystem and plays an important role in aquatic systems by distributing nutrients from the bottom of the riverbed to the surface, escalation of primary production and fish populations, and sustaining aquatic ecosystem (CSG 2018).

The Gharial is endemic to the Indian Subcontinent, where it occurred historically in the Ganges, Brahmaputra, Indus, and Mahanadi River Systems (Groombridge 1987; Hussain 1999; Singh 1978; Smith 1931; Whitaker 1987);

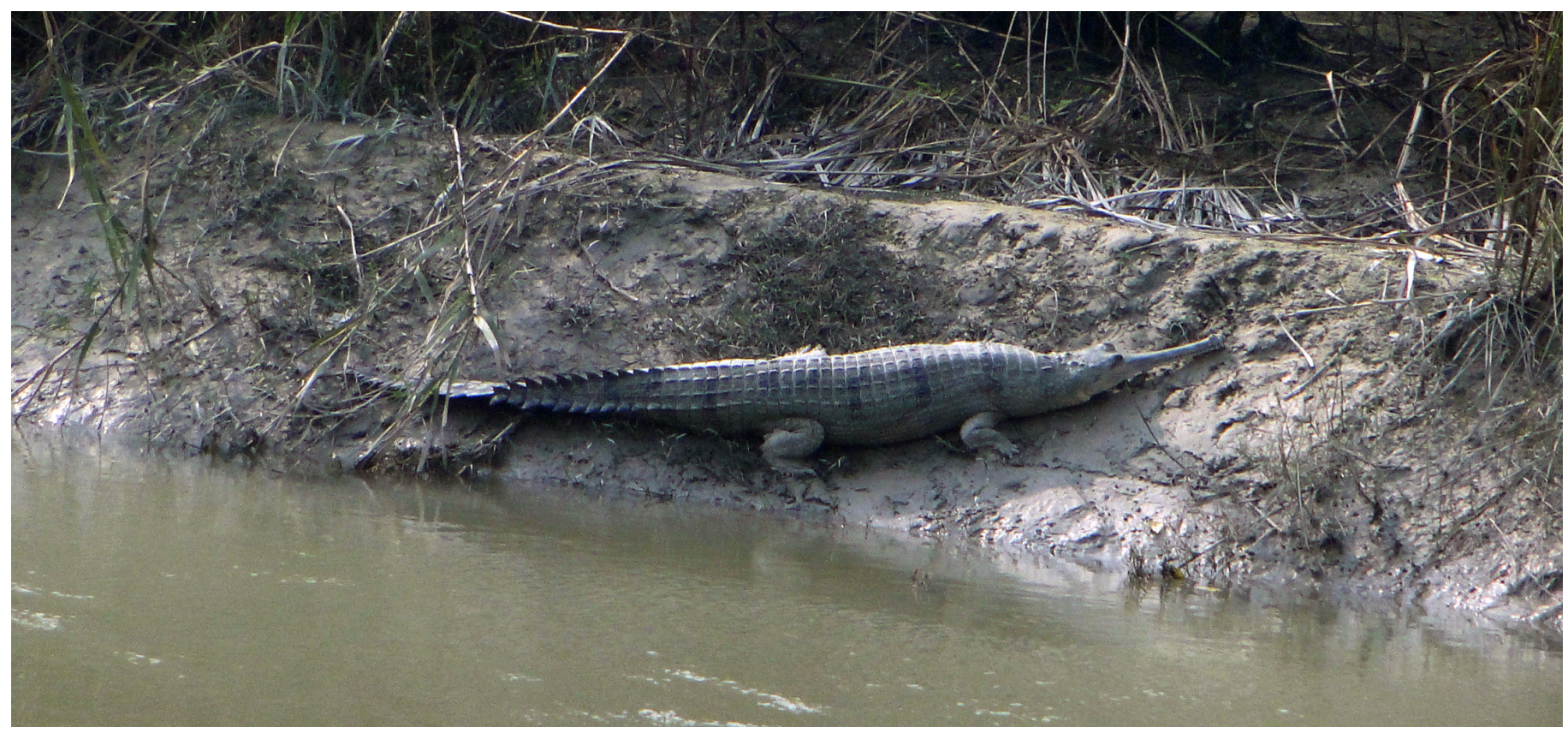

Fig. 1. Basking Indian Gharial (Gavialis gangeticus) on the bank of the Lower Ganga Canal, Narora, Uttar Pradesh, India. Photograph by Debanjan Sarkar. 


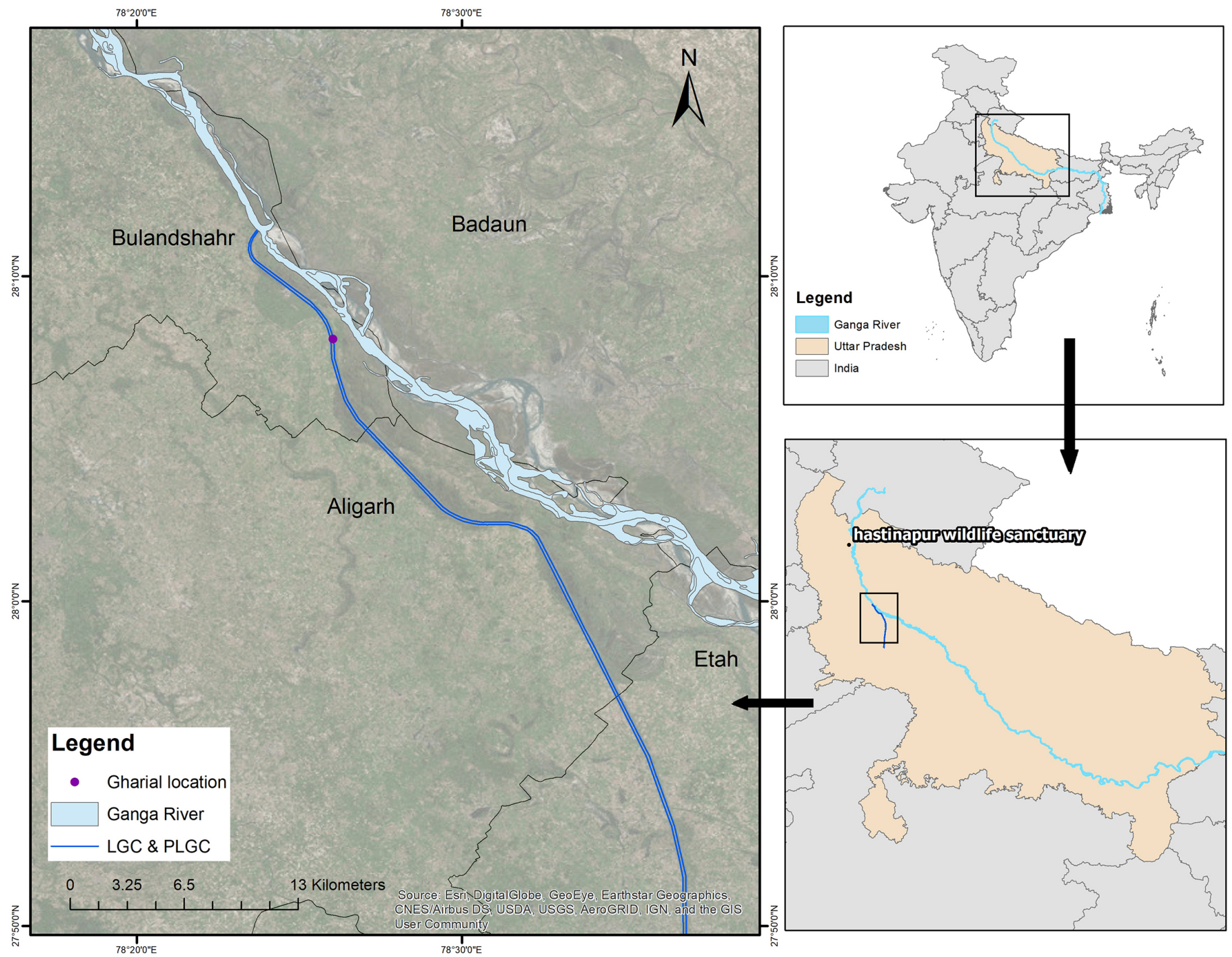

Fig. 2. The study area and the site where an Indian Gharial (Gavialis gangeticus) was sighted along the Lower Ganga Canal, Narora, Uttar Pradesh, India (LGC = Lower Ganga Canal; PLGC = Parallel Lower Ganga Canal).

Smith (1931) also reported its presence in the Irrawaddy River System. The species is now extirpated in Myanmar, Bhutan, and Pakistan (WII-GACMC 2018). During the mid-1970s, populations of Gharial were on the verge of extinction due to habitat loss and hunting (Choudhury and Bustard 1979; Choudhury and Chowdhury 1986; Daniel 1970; Honegger 1971). Other major threats to this species are incidental and intentional fishing activities (Stevenson and Whitaker 2010).

Gharials usually live in large rivers where they share habitat with Muggers (Vasudevan and Sondhi 2010). Surviving small wild populations are restricted to a few river systems in northern and eastern India, Bangladesh, and Nepal (Vasudevan and Sondhi 2010; Maskey and Percival 1994). The current distribution of Gharial in India is about $2 \%$ of the historical range, and numbers have declined about $96 \%$ since 1946 (Whitaker et al. 1974). According to Choudhury et al. (2007), as few as 182 adults remain in the wild in three broadly separated breeding subpopulations in India
(Chambal River, Girwa River, and Son River), one in Nepal (Rapti/Narayani River), and a few other non-breeding sites. Generally, Gharials prefer sandy banks with a water depth greater than $4 \mathrm{~m}$ (WII-GACMC 2018).

The Wildlife Institute of India carried out a biodiversity assessment survey from 24 January to 15 May 2017 along the Lower Ganga Canal in Uttar Pradesh, India. During the survey, we observed a basking Gharial (Gavialis gangeticus; Fig. 1) on the bank of the canal at $28.134515^{\circ} \mathrm{N}, 78.434047 \mathrm{oE}$ (Fig. 2) on 25 January at $1312 \mathrm{~h}$. The individual was about $1.5 \mathrm{~m}$ in length and lacked a ghara on the tip of its snout. During our observation, the Gharial basked until $1401 \mathrm{~h}$ and then entered the water. This individual was sighted only once during the four-month survey. Information on the very few additional recent records of Gharial sighted at nearby locations are in Table 1.

In addition to the Gharial, we encountered 21 Muggers during the survey. Discussions with local inhabitants and fish- 
Table 1. Records of Indian Gharial (Gavialis gangeticus) sightings at locations near the Lower Ganga Canal, Narora, Uttar Pradesh, India.

Location (coordinates and distance from present observation)

Ganga River in Narora $\left(28.383603^{\circ} \mathrm{N}, 78.280328^{\circ} \mathrm{E}\right.$; $25 \mathrm{~km}$ upstream of the canal)

Rescued from the Parallel Lower Ganga Canal $\left(28.19025^{\circ} \mathrm{N}, 78.39481^{\circ} \mathrm{E} ; 7.27 \mathrm{~km}\right.$ upstream) and later released in the Hastinapur Wildlife Sanctuary, Uttar Pradesh $\left(29.15438^{\circ} \mathrm{N}, 78.08388^{\circ} \mathrm{E} ; 160 \mathrm{~km}\right.$ upstream)

Ganga River between Bhagalpur and Sultanganj $\left(25.252544^{\circ} \mathrm{N}, 86.727777^{\circ} \mathrm{E}-25.321388^{\circ} \mathrm{N}\right.$, $86.993611^{\circ} \mathrm{E} ; 1,040 \mathrm{~km}$ downstream)

Ganga River below the Bhimgoda Barrage $\left(29.94697^{\circ} \mathrm{N}, 78.17339^{\circ} \mathrm{E} ; 250 \mathrm{~km}\right.$ upstream)

Ganga River between Brijghat and Bijnor $\left(29.33879^{\circ} \mathrm{N}, 78.55199^{\circ} \mathrm{E}-28.7882^{\circ} \mathrm{N}, 78.75184^{\circ} \mathrm{E}\right.$;

$85-160 \mathrm{~km}$ upstream)

ermen revealed that Muggers were sighted frequently in the canal, although they do not see them in the Ganga River. We also recorded nine species of freshwater turtles (Threestriped Roofed Turtle, Batagur dhongoka; Spotted Pond Turtle, Geoclemys hamiltonii; Indian Peacock Soft-shelled Turtle, Nilssonia hurum; Indian Roofed Turtle, Pangshura tecta; Brown Roofed Turtle, Pangshura smithii; Indian Tent Turtle, Pangshura tentoria; Indian Soft-shelled Turtle, Nilssonia gangetica; Crowned River Turtle, Hardella thurjii; Rock Terrapin, Melanochelys trijuga), the first three of which are considered threatened.

The Lower Ganga Canal (Fig. 3) was built in 1879 for the purpose of delivering water from the Ganga River to water-scarce areas of Uttar Pradesh. The canal is $90 \mathrm{~km}$ long and about 60 meters wide. However, because the canal was unlined, it has developed its own riparian ecosystem with vegetation including cattails (Typha sp.), sedges (Saccharum sp.), buckthorns (Ziziphus sp.), dogbanes (Calotropis sp.), and mimosas (Albizia sp.). Consequently, many freshwater species enter the canal from the Ganga River. A recent proposal to line the Lower Ganga Canal would affect the riparian habitat. The feeder canal that parallels the Lower Ganga Canal already has been lined. We strongly recommended that proper mitigation measures be taken before lining the canal so that the flora and fauna of this freshwater ecosystem might persist.

\section{Acknowledgments}

We are thankful to the Director and Dean of the Wildlife Institute of India for their encouragement to carry out this study. For financial support, we acknowledge the National Mission for Clean Ganga and the Ministry of Water Resources, River Development and Ganga Rejuvenation for the imple-

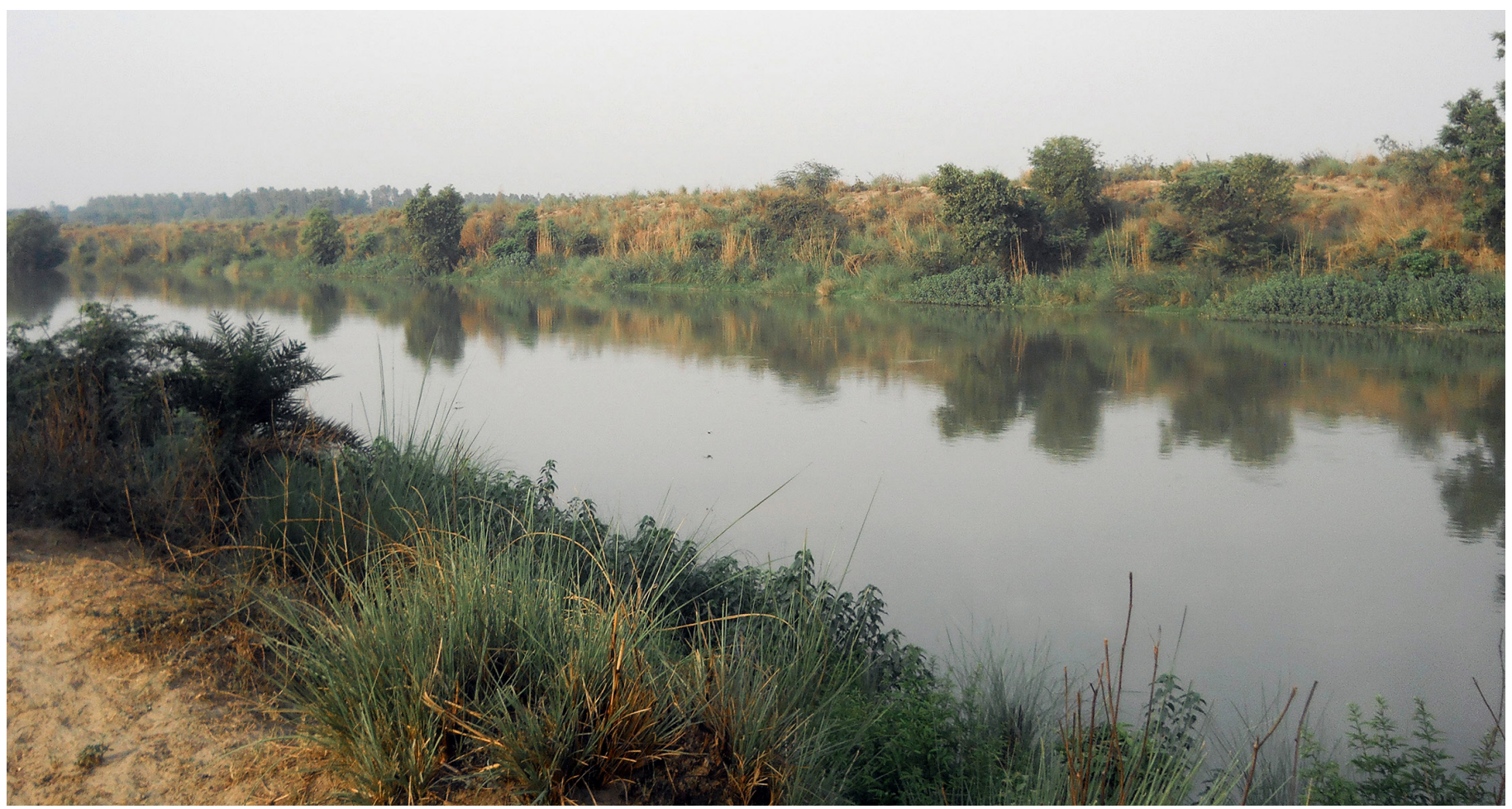

Fig. 3. View of the Lower Ganga Canal. Photograph by Debanjan Sarkar. 
mentation of the "Biodiversity Conservation and Ganga Rejuvenation” project. We also thank the Nuclear Power Corporation of India-Narora for support during the survey, the irrigation department for permitting the study, and Pranab Pal and Anindita Debnath for assistance during the fieldwork.

\section{Literature Cited}

Choudhury, B.C. and H.R. Bustard. 1979. Predation on natural nests of the Saltwater Crocodile (Crocodylus porosus Schneider) on north Andaman Islands with notes on the crocodile population. Journal of the Bombay Natural History Society 76: 311-323.

Choudhury, B.C. and S. Chowdhury. 1986. Lessons from crocodile reintroduction projects in India. The Indian Forester 112: 881-890.

Choudhury, B.C., L.A.K. Singh, R.J. Rao, D. Basu, R.K. Sharma, S.A. Hussain, H.V. Andrews, N. Whitaker, R. Whitaker, J. Lenin, T. Maskey, A. Cadi, S.M.A. Rashid, A.A. Choudhury, B. Dahal, U. Win Ko Ko, J. Thorbjarnarson, and J.P. Ross. 2007. Gavialis gangeticus. The IUCN Red List of Threatened Species 2007: e.T8966A12939997 (http://dx.doi. org/10.2305/IUCN.UK.2007.RLTS.T8966A12939997.en).

CSG (Crocodile Specialist Group). 2018. Gharial (Gavialis gangeticus) (http://www. iucncsg.org/content_images/attachments/species_descriptions/Gharial.pdf).

Daniel, J.C. 1970. A review of the present status and position of endangered species of Indian reptiles, pp. 75-76. In: IUCN Eleventh Technical Meeting. Papers and Proceedings. New Delhi, India, 25-28 November 1969. Volume II. Third Session: Survival Service Commission. Problems of Threatened Species. IUCN, Morges, Switzerland.

GCA (Gharial Conservation Alliance). 2008. International Gharial Recovery Action Plan. (http://www.gharialconservation.org/PDF/GRAP.pdf).

Groombridge, B. 1987. The distribution and status of world crocodilians, pp. 9-21. In: G.J.W. Webb, S.C. Manolis, and P.J. Whitehead (eds.), Wildlife Management: Crocodiles and Alligators. Surrey Beatty and Sons, Chipping Norton, Australia.

Honegger, R.E. 1971. The status of four threatened crocodilian species of Asia, pp. 44-50 In: Crocodiles. Proceedings of the First Working Meeting of Crocodile Specialists: Sponsored by the New York Zoological Society and organized by the Survival Service Commission, IUCN, at the Bronx Zoo, New York. 15-17 March, 1971. IUCN, Morges, Switzerland.
Hussain, S.A. 1999. Reproductive success, hatchling survival and rate of increase of Gharial Gavialis gangeticus in National Chambal Sanctuary, India. Biological Conservation 87: 261-268.

Martin, S. 2008. Global diversity of crocodiles (Crocodilia, Reptilia) in freshwater. Hydrobiologia 595: 587-591.

Maskey, T. M. and H.F. Percival. 1994. Status and conservation of Gharial in Nepal, pp. 190-194. In: Crocodiles: Proceedings of the 12th Working Meeting of the Crocodile Specialist Group. IUCN, Gland, Switzerland.

Nawab, A., R.K. Sinha, P.M. Thompson, and S. Sharma. 2016. Ecosystem services and conservation assessment of freshwater biodiversity, pp. 188-204. In: L. Bharati, B.R. Sharma, and V. Smakhtin (eds.), The Ganges River Basin: Status and Challenges in Water, Environment and Livelihoods. Routledge, Taylor and Francis Group, London, UK.

NPCIL-NAPS. 2015. Survey of River Ganges between Narora to Brijghat. Nuclear Power Corporation of India Limited, Narora Atomic Power Station, Uttar Pradesh, India.

Singh, L.A.K. 1978. Ecological studies on the Indian Gharial (Gavialis gangeticus, Gmelin, Reptilia, Crocodylia). Unpublished Ph.D. Thesis, Utkal University, Bhubaneswar, India.

Smith, M.A. 1931. The Fauna of British India, including Ceylon and Burma. Reptilia and Amphibia. Volume 1 - Loricata, Testudines. Trustees of the British Museum, London, UK.

Stevenson, C. and R. Whitaker. 2010. Indian Gharial Gavialis gangeticus, pp. 139143. In: S.C. Manolis and C. Stevenson (eds.), Crocodiles. Status Survey and Conservation Action Plan. Third Edition. Crocodile Specialist Group, Darwin, Northern Territory, Australia.

Vasudevan, K. and S. Sondhi. 2010. Amphibians and Reptiles of Uttarakhand, India. Wildlife Institute of India, Dehradun, Uttarakhand, India.

WII-GACMC. 2018. Ganga River - State of Biodiversity at a Glance. Ganga Aqualife Conservation Monitoring Centre, Wildlife Institute of India, Dehradun, Uttarakhand, India.

Whitaker, R., V. Rajamani, D. Basu, and V. Balakrishnan. 1974. Preliminary Survey of the Gharial (Gavialis gangeticus). Madras Snake Park Trust Report, Chennai, India.

Whitaker, R. 1987. The management of crocodilians in India, pp. 63-72. In: G.J.W. Webb, S.C. Manolis, and P.J. Whitehead (eds.), Wildlife Management: Crocodiles and Alligators. Surrey Beatty and Sons, Chipping Norton, Australia.

Yadav, S.K. and M.S. Khan. 2016. Note on Gharial reintroduction and rescue in Upper Ganga River. Crocodile Specialist Group Newsletter 35(4): 6-8. 